IRA-International Journal of Education \& Multidisciplinary Studies

ISSN 2455-2526; Vol.03, Issue 03 (2016)

Institute of Research Advances

http://research-advances.org/index.php/IJEMS

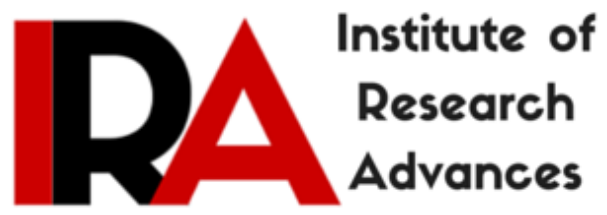

\title{
Teaching-Learning Approaches and Strategies in Peace Education
}

\author{
Dr. A. Subramanian, \\ Assistant Professor, \\ Department of Education, \\ University of Madras, Chennai-5, India.
}

DOI: http://dx.doi.org/10.21013/jems.v3.n3.p9

\section{How to cite this paper:}

Subramanian, D. (2016). Teaching-Learning Approaches and Strategies in Peace Education. IRA International Journal of Education and Multidisciplinary Studies (ISSN 2455-2526), 3(3). doi:http://dx.doi.org/10.21013/jems.v3.n3.p9

(C) Institute of Research Advances

\section{(cc) BY-NC}

This works is licensed under a Creative Commons Attribution-Non Commercial 4.0 International License subject to proper citation to the publication source of the work.

Disclaimer: The scholarly papers as reviewed and published by the Institute of Research Advances (IRA) are the views and opinions of their respective authors and are not the views or opinions of the IRA. The IRA disclaims of any harm or loss caused due to the published content to any party. 


\section{ABSTRACT}

The "how" is as "important" as the "what". Hence, the teaching-learning approaches that are compatible with the goals of peace education are holistic, participatory, cooperative, experiential and humanist. Holistic education does not confine itself to the parameters of facts and concepts. Instead, it promotes cognitive, affective and behavioural goals of learning. Often, the focus of learning is the transmission of concepts. In peace education, the goals are three-fold. First is the building of awareness on the realities, roots and consequences of violence, and the building of awareness on the roots of peace. Second is the building of concern and the development of the values of empathy, compassion, hope and social responsibility. In 2003, Harris and Morrison call it the development of moral sensitivity culminating in the building of the capacity of learners to care for others. Third is the call to action beginning with the resolve to change personal mindsets and attitudes and doing something concrete about situations of violence. Participatory education means allowing learners to inquire, share and collaborate. It allows learners to engage in dialogue with the teacher or with their co-learners. The practice of articulating and listening to diverse points of view is an important exercise in broadening perspectives. Such a skill is necessary in a world where many conflicts remain unresolved because of peoples' refusal to hear one another. In participatory learning, teacher acts more as a facilitator rather than an authority figure. Even if teachers have definite stands on issues, they should encourage students to articulate their own perspectives before inviting them to take appropriate action on the issues discussed (Mcginnis, 1984). Participatory education also means veering away from the traditional indoctrination style. The observance of democratic processes in the classrooms can contribute to the development of knowledge, skills and attitudes necessary for democratic citizenship (Harris and Morrison, 2003). Carl Rogers and Abraham Maslow are proponents of a type of education that is humanist. A humanist classroom emphasizes the social, personal and affective growth of the learners. In a humanistic classroom, individuals are accepted for what they are. It develops the notions of the self to promote a sense of self-esteem. It sends the message that all are valuable and gifted. Mcginnis (1984) says that "without a positive self-concept or self-image, no one takes a stand, 'goes public', or works for change". He also posits that the more aware we are of our giftedness, the more willing we become to share our gifts with others. Teachers in a humanist classroom are empathetic and affirming. They show interest and concern for the well-being of their students. They encourage in the classroom care and respect for each other. They also encourage sensitivity to diversity in the classroom. Such approach will help breed in learners the seeds of love and compassion-values that are necessary in building a peaceable society.

Keywords: Peace education, Role play, Problem-solving, Brainstorming.

\section{Introduction:}

The "how" is as "important" as the "what". Hence, the teaching-learning approaches that are compatible with the goals of peace education are holistic, participatory, cooperative, experiential and humanist.

Holistic education does not confine itself to the parameters of facts and concepts. Instead, it promotes cognitive, affective and behavioural goals of learning. Often, the focus of learning is the transmission of concepts. In peace education, the goals are three-fold. First is the building of awareness on the realities, roots and consequences of violence, and the building of awareness on the roots of peace. Second is the building of concern and the development of the values of empathy, compassion, hope and social responsibility. In 2003, Harris and Morrison call it the 
development of moral sensitivity culminating in the building of the capacity of learners to care for others. Third is the call to action beginning with the resolve to change personal mindsets and attitudes and doing something concrete about situations of violence.

Participatory education means allowing learners to inquire, share and collaborate. It allows learners to engage in dialogue with the teacher or with their colearners. The practice of articulating and listening to diverse points of view is an important exercise in broadening perspectives. Such a skill is necessary in a world where many conflicts remain unresolved because of peoples' refusal to hear one another. In participatory learning, teacher acts more as a facilitator rather than an authority figure. Even if teachers have definite stands on issues, they should encourage students to articulate their own perspectives before inviting them to take appropriate action on the issues discussed (Mcginnis, 1984). Participatory education also means veering away from the traditional indoctrination style. The observance of democratic processes in the classrooms can contribute to the development of knowledge, skills and attitudes necessary for democratic citizenship (Harris and Morrison, 2003).

Cooperative learning means giving opportunities for participants to work together and learn, rather than compete with each other. Cooperative learning, aside from increasing motivation to learn, improves relations among students; challenges individualism; and lessens divisiveness and feelings of prejudice. It reverses feelings of alienation and isolation and promotes more positive attitudes. In a cooperative classroom, students learn to rely on each other, and the success of learning activities depends upon the contributions of each one (Harris and Morrison, 2003). Many of the problems in the word we face right now can be solved if people would cooperate. If students would experience cooperative processes in the classroom, such habit could be brought by them into their larger spheres of interaction.

Experiential education means learning not through didactic means but through the processing of one's experience from activities initiated in the classroom. Hence, lectures are kept to a minimum. Learners build ideas and form their own concepts from the experience or activity they went through. In educational psychology, this approach is close to the constructivist approach. Constructivist teachers are flexible and process-oriented. They allow space for change. A constructivist classroom will help develop humans who are skilled in developing new paradigms. Our world needs new ways of thinking and new processes to challenge the systems that breed violence and conflicts.

Carl Rogers and Abraham Maslow are proponents of a type of education that is humanist. A humanist classroom emphasizes the social, personal and affective growth of the learners. In a humanistic classroom, individuals are accepted for what they are. It develops the notions of the self to promote a sense of self-esteem. It sends the message that all are valuable and gifted. Mcginnis (1984) says that "without a positive self-concept or self-image, no one takes a stand, 'goes public', or works for change". He also posits that the more aware we are of our giftedness, the more willing we become to share our gifts with others. Teachers in a humanist classroom are empathetic and affirming. They show interest and concern for the well-being of their students. They encourage in the classroom care and respect for each other. They also encourage sensitivity to diversity in the classroom. Such approach will help breed in learners the seeds of love and compassion- values that are necessary in building a peaceable society.

There are many teaching learning strategies that are compatible with the approaches to peace education described above. They are as follows: 


\section{Discussion}

The small group discussion is a strategy that is used to enable the individual participant's voice to be heard. To be most effective, a discussion has to be based on factual information and good thought-out ideas.

\section{Pair Share}

It is a discussion technique where partner groups are formed. Facilitator poses a question or topic for discussion. Person A responds to the question uninterrupted while B listens. After a given time, partners reverse roles. Later, A relates to the class the points $\mathrm{B}$ expressed and vice-versa. It is a good exercise to improve listening skills.

\section{Visualization/Imagination Exercise}

The visualization exercise helps the participants to use their imagination. It allows them to imagine alternatives, to, for example, situations of conflict.

\section{Perspective-taking}

In this strategy, learners are asked to understand and appreciate where the other person is coming from. It is a skill used in problem-solving. This entails "standing in the shoe of the other and walking in them for a while". This device is often used to develop empathy and tolerance.

\section{Role-playing}

This strategy is used to provide the participants with the opportunity to "feel" the situation rather than merely intellectualize about it. Role-playing also develops empathy and greater understanding for other vantage points. It can cultivate both cognitive and affective learning.

\section{Simulation Games}

Simulating situations of violence, for instance, allows learners to have a better feel of the situation of peacelessness and allows them to be more creative in suggesting alternatives to the situation of injustice. An example is the simulation on the distribution of wealth in "Sharing the Earth's Resources".

\section{Problem-solving}

Problem-solving is one of the most valuable learning strategies. It enables the person to use other valuable cognitive skills such as analyzing, generating options and evaluating options.

\section{Considering positions/Issue Poll}

This activity is used to surface the differing positions of participants to a controversial statement as in the case of the statement, "Whether we like it or not, wars will happen in the future." There can be at least three positions vis-à-vis controversial statements: agree, not sure/neutral, disagree.

\section{Encouraging action}

Whenever appropriate, the participants are asked to express a resolution or commitment to certain actions as a form of application of learning(s). 


\section{Reading or Writing a Quotation}

The reading of a peace-related quotation in the beginning or at the end of a lesson encourages learner to think or appreciate better the concepts learned in the session.

\section{Web-Charting}

Writing a word such as "war" or "peace" on the board in the beginning of a session and inviting learners to write or draw their associations with the word stimulate thinking. It is also a good springboard for the discussion of a particular peace-related concept.

\section{Use of Film and Photographs}

The showing of film and/or photographs help create vivid images in the minds of the learners. This can be followed by a discussion on messages conveyed and learners' reactions.

\section{Telling Stories, including Personal Stories}

Learners sometimes remember the concepts we want to share through our anecdotes and stories. Sharing your personal experiences related to the issue will help illustrate better the points you want to make. Such strategy also helps learners connect with you on a more personal basis.

\section{Song/Poem Analysis}

Many songs and poems contain peace-related messages. Allowing your students to listen to or read them, identify their favorite lines, and interpret messages will help them learn the values you want to impart in a more creative manner.

\section{Sentence Completion}

Encouraging learners to complete unfinished sentences will help you know what thoughts and feelings they may have about a particular topic. The strategy may also be used to solicit action ideas from the participants.

\section{Journal Writing/Individual Reflection}

At the end of a session, you may want to invite participants to answer one or two questions that will allow them to think of their responses/reflections/reactions to an issue that has just been discussed.

\section{Go-Round}

It is a strategy where the opinion of each participant is briefly solicited.

\section{Teachable Moments}

It is an opportunity seized by the teacher to discuss the hot issue of the day. It may be an issue that is internal to the class (e.g., an ongoing conflict).

\section{Interviews/Research}

Learners get the chance to gather information from third sources. Asking students to interview peace advocates, for instance, would help them appreciate what others do to help build a culture of peace. 


\section{Expert Resources}

Learners are exposed to the ideas of advocates for justice and peace. The use of a third person is most helpful for very controversial topics.

\section{Reciprocal Teaching}

Students take turn in facilitating. "What we hear, we usually forget; what we see, we usually remember; but what we do, we better understand." When given a chance to teach the subject matter, students are given the chance to comprehend better the concepts, values and skills we want to impart.

\section{Twinning Projects}

Students may partner with another person from a different locality via e-mail or regular mail to discuss topics related to peace.

\section{Dialogues}

Students are given the opportunity to converse, rather than debate, about problematic issues. In debates, the goal is to prove each other wrong. Dialogues, on the other hand, are occasions to find common grounds.

\section{Exposure Trips}

Students are given the opportunity to be touched by victims of injustice. Seeing, hearing, and encountering a victim of violence is more powerful in developing empathy and compassion among the learners. Contact opportunities also motivate better in prodding students to action.

\section{Use of globes and maps}

A constant show of these devices will remind learners that there are people from other countries to care for and be concerned about other than one's own.

\section{Brainstorming}

It is a method that helps people think creatively by letting many ideas flow from the students without any comment from the others. This strategy can be useful in generating many different solutions or alternatives. Evaluation of the ideas is done after the brainstorming.

\section{Reading quotations}

Peace activists, religious leaders, indigenous community leaders, and philosophers have said words of wisdom and inspiration that relate to peace. Let your students ponder on these quotations and speak about the impact of these ideas on them.

\section{Use of Charts and Graphs}

Statistics do not have an impact on students in the same way that contact with victims of injustice does, but statistics still help in giving learners an idea of the extent and magnitude of problems in society. The Human Development Report, an annual publication of the UNDP, is a rich resource for facts and figures.

\section{Case Studies}

This strategy gives the students an opportunity to know real-life situations of violence or injustice. Case studies are stories or scenarios that require analysis 
and invite solutions. Students are put in the position of problem solvers who discover underlying issues, positions and interests.

\section{Collage-making}

A collage is a collection of photos from various sources that are put together to make a whole. Asking students to make a collage on issues that relate to peace will help them understand those issues better.

\section{Show and Tell}

This strategy gives the student an opportunity to explain a concept to his/her classmates with matching visual aids, and is premised on the belief that if one can explain a concept well to someone else, this person, without doubt, understands the concept.

\section{Conclusion:}

These approaches and strategies are important tools toward the development of the students' intellect, attitudes and spirit that they may be inspired to work for peace. In deciding what approach or strategy to take, the particular lesson/session objectives have to be considered. Which strategies would be most appropriate and effective in achieving the latter? As we use the foregoing tools, let us always be mindful of our goal, which is to facilitate learning that is holistic, participatory collaborative, experiential and humanist.

\section{References:}

1. Harris, I. and Morrison, M. (2003). Peace education. Jefferson, North Carolina: McFarland and Company, Inc.

2. Hicks, D. (1987). Education for peace: principles into practice. Cambridge Journal of Education, 17.

3. Jones, T. (2006). Combining conflict resolution education and human rights education: thoughts for school-based peace education. Journal of Peace Education, 3(2).

4. Toh, S. H. (2004). Learning to live together: teachers resource book on education for international understanding. Seoul: APCEIU

5. Harris, Ian 2010. History of Peace Education, in: Gavriel Salomon \& Ed Cairns (Eds.). Handbook on Peace Education. New York: Psychology Press, $11-20$. 